\title{
Penerapan Konsep Instrumen Evaluasi Hasil Belajar
}

\author{
Yossita Wisman*, Effrata, Tutesa \\ Fakultas Keguruan dan Ilmu Pendidikan, Universitas Palangka Raya, Indonesia \\ E-mail: yossitayosie@yahoo.com
}

Diterima: 22 Desember 2020; Disetujui: 4 Januari 2020; Diterbitkan: 22 Januari 2021

\begin{abstract}
ABSTRAK
Dalam tulisan membahas tentang efektivitas pembelajaran dilihat dari segi proses dan hasil dari suatu pembelajaran. Proses dan hasil dari suatu pembelajaran sendiri sering disebut dengan evaluasi. Evaluasi guna untuk mencapai suatu tujuan pendidikan dalam sebuah pembelajaran. Penelitian ini juga bertujuan untuk mengetahui keefektifan pelaksanaan pembelajaran dan pencapaian hasil pembelajaran oleh setiap siswa. Informasi kedua hal tersebut pada gilirannya sebagai masukan untuk meningkatkan kualitas proses dan hasil pembelajaran. Manfaat dilaksanakannya evaluasi proses dan hasil pembelajaran ada beberapa hal, diantaranya yang penting ádalah: (1) Memperoleh pemahaman pelaksanaan dan hasil pembelajaran yang telah dilaksanakan guru, (2) Membuat keputusan berkenaan dengan pelaksanaan dan hasil pembelajaran, dan (3) Meningkatkan kualitas proses dan hasil pembelajaran dalam rangka upaya meningkatkan kualitas keluaran.
\end{abstract}

Kata kunci : evaluasi hasil belajar, instrumen, konsep

\section{PENDAHULUAN}

Dunia pendidikan saat ini dituntut untuk mengembangkan pendekatan pembelajaran sesuai dengan dinamika pendidikan Negara kita, yang berakar pada UUD 45 dan UU No. 20 Tahun 2003 yang berakar pada nilai-nilai agama, kebudayaan nasional Indonesia dan tanggap terhadap tuntutan zaman dan sesuai dengan perkembangan IPTEK.

Pendidikan selalu menjadi sorotan banyak orang, tidak hanya dari pemegang kebijakan tetapi juga pengguna (siswa). Saat ini dan masa depan pendidikan akan menjadi tantangan yang akan terus berubah disesuaikan dengan standar Pengembangan IPTEKS. Sebagaimana Nurdyansyah juga mempertegas bahwa: "Educational process is the process of developing student's potential until they become the heirs and the developer of nation's culture". Oleh karena itu Duschl mengatakan bahwa Pendidikan adalah bagian dari rekayasa sosial. Melalui komunitas, pendidikan dapat dibentuk dan diarahkan ke tujuan tertentu.

Permasalahan bangsa yang semakin hari semakin pelik dengan adanya berbagai krisis multi dimensi ditambah dengan pengaruh dari arus informasi memunculkan beragam bentuk perilaku di masyarakat khususnya bagi para 
peserta didik. Perkembangan teknologi merupakan sesuatu yang tidak bisa kita hindari dalam kehidupan ini. Sehingga keluarga harus berperan aktif dalam mendidik anaknya sejak dini serta menguatkan pondasi karakter yang baik.

Pada kenyataannya masih banyak permasalahan yang harus dihadapi dalam rangka meningkatkan mutu pendidikan di Indonesia. Permasalahan ini dipengaruhi oleh sejumlah faktor eksternal yang berasal dari luar peserta didik, maupun faktor internal yang berasal dari dalam diri peserta didik itu sendiri.

Nurdyansyah meperejelas "The education world must innovate in a whole. It means that all the devices in education system have its role and be the factors which take the important effect in successful of education system".

Proses pembelajaran hendaknya berlangsung secara interaktif, inspiratif, menyenangkan, menantang, memotivasi peserta didik untuk berpartisipasi aktif, serta memberikan ruang yang cukup bagi prakarsa, kreativitas, dan kemandirian sesuai dengan bakat dan minat peserta didik. Proses pembelajaran harus melibatkan banyak pihak, yang diimbangi oleh perkembangan teknologi untuk mempermudah dalam tercapaianya suasana tertentu dalam proses pembelajaran sehingga peserta didik nyaman dalam belajar. Hakikat belajar yaitu suatau proses pengarahan untuk pencapaian tujuan dengan melakukan perbuatan melalui pengalaman yang diciptakan.

Bahan ajar berguna membantu pendidik dalam melaksanakan kegiatan pembelajaran. Bagi pendidik bahan ajar digunakan untuk mengarahkan semua aktivitasnya dan yang seharusnya diajarkan kepada siswa dalam proses pembelajaran.

Pengalaman belajar tersebut perlu adanya standarisasi penilaian hasil belajar. Penilaian hasil belajar memerlukan sebuah pengolahan dan analisis yang akurat, sehingga pembelajaran dapat berjalan efektif dan efisien.

Pemahaman terhadap konsep dasar penilaian dalam pembelajaran merupakan syarat wajib bagi seorang guru agar ia mampu menilai hasil belajar siswa dengan baik. Pemahaman konseptual ini sangat diperlukan agar guru mempunyai dasar yang kuat dalam menilai hasil belajar siswa.

Pada saat kita mendiskusikan permasalahan dalam penilaian hasil belajar, biasanya kita akan menemukan beberapa istilah yang sering digunakan. Beberapa istilah tersebut adalah dalam konteks evaluasi. Kami akan membahas tentang evaluasi, cara menerapkan konsep instrumen hasil belajar tersebut.

Evaluasi pembelajaran sendiri dilaksanakan guna mengetahui sejauh mana pengetahuan siswa, disini evaluasi dalam artian sempit. Sedangkan dalam pengertian yang lebih luas, evaluasi pembelajaran sendiri untuk mengukur tingkat keberhasilan dan kegagalan suatu proses pembelajaran dalam mencapai suatu tujuan pendidikan yang diharapkan.

Dapat difahami betapa pentingnya evaluasi pembelajaran dalam proses pendidikan merupakan bagian penting dari pendidikan pada ummumnya dan dapat dilihat setelah dilakukan observasi pembelajaran tingkat kelulusan. Jika hasil 
lulusan, sesuai dengan apa yang telah diharapkan dalam tujuan pendidikan, maka usaha pendidikan dapat dikatakan berhasil, tetapi jika sebaliknya, maka ia dikatakan gagal.

Proses evaluasi pembelajaran sangat berperan penting untuk mengetahui sejauh mana perkembangan siswa. Guna menentukan keputusan yang dilakukan selanjutnya oleh pendidik. maka dari itu, evaluasi dikatakan penting dan wajib untuk semua yang berperan dalam dunia pendidikan untuk menerapkan evaluasi pada peserta didik.

Setiap perbuatan dan tindakan dalam evaluasi pembelajaran selalu menghendaki hasil. Pendidik selalu berharap bahwa hasil yang diperoleh sekarang lebih baik dan memuaskan dari hasil yang diperoleh sebelumnya, untuk menentukan dan membandingkan antara satu hasil dengan lainnya diperlukan adanya evaluasi pembelajaran.

Pembelajaran Evaluasi menekankan pada hasil evaluasi pembelajaran yang dilakukan terhadap siswa termasuk keefektifan strategi pembelajaran yang dilaksanakan, keefektifan media guru dalam pembelajaran, cara mengajar yang dilaksanakan, dan minat, sikap serta cara belajar yang dilakukan oleh siswanya.

Teknik melaksanakan evaluasi sering disebut jenis tagihan evaluasi hasil pembelajaran, sedangkan bentuk instrumen evaluasi hasil pembelajaran adalah alat evaluasi yang dipakai untuk memungut data hasil pembelajaran. Penyusunan tagihan adalah strategi guru dalam memberikan tugas belajar berupa pengalaman langsung di kelas atau di luar kelas. Istilah pemberian tugas disini lebih dikenal dengan tagihan belajar.

\section{PEMBAHASAN}

Jenis tagihan belajar ditentukan oleh materi yang disusun dan akan diajarkan. Secara garis besar tagihan belajar harus dikembangkan sesuai kompetensi dan indikator. Misalnya ketika guru ingin meminta tagihan belajar menyangkut hal yang berkenaan dengan pengetahuan dan pemahaman. Maka tagihan yang harus dikembangkan berupa tagihan dalam ranah kognitif.

Jenis tagihan yang dapat digunakan dalam penilaian berbasis kompetensi dasar dapat terkait aspek kognitif atau psikomotor. Dikarenakan data dan informasi tersebut yang menjadi dasar penentu sejauh mana tingkat keberhasilan peserta didik dalam penguasaan kompetensi dasar yang diajarkan.

Jikalau bisa, guru sebaiknya melakukan evaluasi setiap hari, misalnya menelaah efektivitas suatu perencanaan program keunggulan siswa, yaitu menghitung setiap tingkat ketercapaian suatu program tujuan atau sasaran pendidikan yang ingin dicapai. Penilaian semacam ini disebut penilaian reflektif. Sedang penilaian tentang efisiensi proses program disebut penilaian formatif, dan perihal kesahihan (validitas) dan keterandalan (reliabilitas).

Penilaian hasil pelaksanaan program kegiatan belajar disebut penilaian sumatif. Proses pembelajaran di kelas sangat banyak yang perlu dinilai. Misalnya 
program pembelajaran dikelas, ungkapan nalar anak saat bermain, dampak kegiatan tertentu dalam proses pembelajaran baik yang positif maupun negatif, dan sebagainya. Singkatnya adalah segala kegiatan yang dapat menolong guru memperoleh suatu gambaran yang jelas tentang program belajar dan pembelajaran yang telah dilaksanakannya perlu dilakukan penilaian.

Semua aspek memang dapat dievaluasi, termasuk mengevaluasi hasil asesmen mengenai belajar dan perkembangan anak didik, terhadap rekan kerja, evaluasi diri, juga evaluasi keseluruhan program kegiatan belajar dan pembelajaran serta pengelolaannya.

Dilihat dari pola pelaksanaannya, dapat dikatakan bahwa penilaian berbasis kelas merupakan suatu tagihan yang diminta guru kepada siswa terhadap kompetensi yang telah ditetapkan. Tagihan-tagihan tersebut terdiri atas beberapa jenis, antara lain:

1. Kuis. Soal isian singkat. Dilaksanakan dalam waktu yang cepat misalnya 15 menit saja, dan hanya menanyakan hal-hal yang prinsip. Kuis biasanya diberikan sebelum pelajaran baru dimulai yaitu untuk mengethui pelajaran yang lalu. Bisa juga diberikan setelah pelajaran akan selesai, yaitu untuk mengetahui pemahaman peserta didik terhadap pelajaran yang baru diberikan itu. Bila ada bagian yang belum dikuasai sebaiknya guru menjelaskan kembali dengan metode yang lain.

2. Pertanyaan lisan di kelas. Pertanyaan lisan ini juga diberikan saat awal atau akhir pelajaran, guna mengukur sejauh mana pemahaman siswa tentang materi yang sudah diajarkan. Materi yang ditanyakan berupa teori, konsep atau hal yang umum yang sudah dipelajari sebelumnya. Teknik bertanya secara lisan disini guru memberikan pertanyaan secara dan memberikan waktu untuk peserta didik yang bisa menjawab pertanyaan, selanjutnya guru menyimpulkan jawaban dari pertanyaan tersebut.

3. Ulangan harian. Uji coba oleh guru yang dilakukan secara berkala, misalnya satu atau dua kompetensi dasar selesai diajarkan. Bentuk soal yang digunakan sebaiknya bentuk uraian objektif atau uraian nonobjektif. Tingkat berfikir yang terlibat dalam ulangan harian ini harus mencakup pemahaman, analisis, dan aplikasi.

4. Tugas individu. Tugas dalam bentuk atau soal uraian objektif atau non objektif. Tingkat berpikir yang terlibat sebaiknya aplikasi, analisis, bila mungkin sampai sintesis dan evaluasi.

5. Tugas kelompok. Tugas kelompok dapat terkait dengan ranah psikomotor. Tugas ini memerlukan tingkat berpikir tinggi yaitu aplikasi sampai evaluasi. Disini peserta didik dimintai data sungguhan dari hasil pengamatan terhadap suatu gejala atau peserta didik merencanakan suatu proyek menggunakan data sungguhan dari lapangan. 
6. Ulangan blok. Tingkat berpikir yang terlibat dari ranah pemahaman sampai dengan evaluasi. Bentuk soal dapat berupa pilihan ganda, uraian, atau campuran. Materi yang diujikan harus berdasarkan kisi-kisi soal.

7. Laporan kerja praktek atau laporan praktikum. Bentuk ini dipakai untuk mata pelajaran yang memerlukan kegiatan praktikum untuk menghasilkan suatu data yang valid, seperti: Fisika, Kimia, Biologi. Peserta didik bisa diminta untuk mengamati suatu gejala dan melaporkannya.

8. Responsi atau ujian praktek, yaitu untuk mengetahui penguasaan akhir baik ranah kognitif maupun psikomotor. Guna mengukur sejauh mana penguasaan peserta didik terhadap materi yang diajarkan dan sejauh mana peserta didik bisa mempraktekkannya.

Secara garis besar, ragam alat evaluasi terdiri atas dua macam bentuk, yaitu:

1. Bentuk Objektif

Bentuk objektif disebut juga dengan tes objektif, yaitu tes yang jawabannya diberi score nilai menurut pedoman yang ditentukan sebelumnya. Tes objektif biasanya disajikan dalam bentuk jawaban, pengisian titik-titik, dan pencocokan satu pernyataan dengan pernyataan lainnya.

2. Bentuk Subjektif

Bentuk evaluasi beruapa soal uraian, yakni soal ujian mengharuskan siswa menjawab setiap pertanyaan dengan cara menguraikan atau dalam bentuk karangan bebas. Alat evaluasi atau pengukur prestasi belajar peserta didik berupa tes yang jawabannya tidak ternilai dengan score atau angka pasti. Hal ini disebabkan banyaknya ragam gaya jawaban yang diberikan oleh peserta didik.

Teknik penilaian diri dapat digunakan dalam berbagai aspek penilaian, yang berkaitan dengan kompetensi kognitif, afektif dan psikomotor. objek yang ingin dinilai sangat diharap mampu minimal untuk menilai dirinya sendiri yang berhubungan dengan status, proses serta tingkat pencapaian kompetensi diri sendiri yang dipelajari dalam mata pelajaran tertentu.

Dalam proses pembelajaran di kelas, berkaitan dengan kompetensi kognitif, misalnya: peserta didik dapat diminta untuk menilai penguasaan pengetahuan dan keterampilan berpikir sebagai hasil belajar dalam mata pelajaran tertentu, berdasarkan kriteria atau acuan yang telah disiapkan. Berkaitan dengan kompetensi afektif, misalnya, peserta didik dapat diminta untuk membuat tulisan yang memuat diary atau curhatan dirinya terhadap suatu sikap terhadap dirinya sendiri atau orang lain. Selanjutnya, peserta didik diminta untuk melakukan penilaian diri berdasarkan kriteria atau soal yang dipersiapkan oleh guru kelas. Berkaitan dengan kompetensi psikomotorik, 
peserta didik dapat diminta untuk menilai keterampilan yang telah dikuasainya sebagai hasil belajar berdasarkan kriteria atau acuan yang disiapkan.

Penilaian diri dilakukan berdasarkan kriteria yang sangat jelas dan menarik objek. Oleh karena itu, penilaian diri terhadap peserta didik di kelas perlu dilakukan melalui langkah-langkah sebagai berikut :

1. Menentukan kompetensi dan kemampuan diri siswa.

2. Menentukan kriteria penilaian yang digunakan guru mata pelajaran.

3. Merumuskan format penilaian, dapat berupa skor dan daftar tanda cek.

4. Guru menilai hasil penilaian secara random, agar dapat mendorong peserta didik dapat melakukan penilaian diri secara baik dan objektif.

5. Memberikan umpan balik kepada peserta didik berupa kalimat yang baik hasil sampel yang diambil secara random tadi.

Agar penilaian berfungsi dengan baik, maka sangat perlu untuk meletakan standar, yang akan menjadi dasar dan pijakan bagi guru dan praktisi pendidikan dalam melakukan kegiatan penilaian. Oleh karena itu, ada beberapa pihak yang berkaitan langsung dengan pelaksanaan kegiatan ini, yaitu:

\section{Peran Guru}

Peranan guru dalam penilaian lebih efektif jika mampu memanfaatkan informasi hasil penilaian melalui umpan balik. Umpan balik merupakan sarana bagi guru dan siswa untuk mengetahui sejauh mana kemajuan pembelajaran yang telah dilakukan.

Boud (1995), memberikan panduan bagi guru dalam memberikan umpan balik pada siswa yaitu: 1) Realistik, 2) Spesifik, 3) Sensitif terhadap tujuan yang bersangkutan, 4) Tepat waktu, 5) Jelas, 6) Tidak menghakimi, 7) Tidak membanding membandingkan, 8) Tekun, 9) Terus terang, 10) Positif, dan 11) Hati-hati.

Untuk dapat memaksimalkan peranannya guru dituntut memiliki profesional yang tinggi. Ada lima hal yang harus dimiliki oleh guru agar dapat dikatakan profesional yaitu:

1) Guru mempunyai komitmen pada siswa dan proses belajarnya.

2) Guru menguasai secara mendalam bahan/mata pelajaran yang diajarkannya serta cara mengajarkannya pada siswa.

3) Guru bertanggung jawab memantau hasil belajar siswa melalui berbagai cara evaluasi.

4) Guru mampu berfikir sistematis tentang apa yang dilakukannya dan belajar dari pengalamannya.

5) Guru seyogyanya merupakan bagian dari masyarakat belajar dalam lingkungan profesi. 
Mengembangkan draf instrumen penilaian merupakan salah satu langkah penting dalam prosedur penilaian, antara lain:.

1. Instrumen penilaian bisa disusun dalam bentuk tes atau nontes, dalam bentuk tes, berarti guru harus membuat soal untuk diberikan kepada siswa.

2. Penilaian sosial adalah penjabaran indikator terhadap pertanyaan yang karakteristi sesuai kisi-kisi yang telah diberikan guru.

3. Setiap pertanyaan harus jelas serta bisa dimengerti oleh siswa, baik bentuk pertanyaan maupun bentuk jawabannya.

4. Kualitas butir soal akan menentukan kualitas tes secara keseluruhan.

5. Dalam bentuk notes, guru dapat membuat angket untuk siswa, pegangan observasi, pegangan wawncara, dokumentasi, dan sebagainya.

\section{KESIMPULAN}

Penilaian berbasis kelas merupakan suatu tagihan yang diminta guru kepada siswa terhadap kompetensi yang telah ditetapkan. Tagihan-tagihan tersebut terdiri atas dua macam, yaitu : Bentuk objektif dan Bentuk subjektif.

Penilaian diri dilakukan berdasarkan kriteria yang jelas dan dengan cara yang objektif. Oleh karena itu, penilaian diri oleh peserta didik di kelas perlu dilakukan melalui langkah-langkah: 1) Menentukan kompetensi atau aspek kemampuan yang akan dinilai. 2) Menentukan kriteria penilaian yang akan digunakan. 3) Merumuskan format penilaian, dapat berupa pedoman penskoran, daftar tanda cek, atau skala rentang. 4) Meminta peserta didik untuk melakukan penilaian diri. 5) Guru mengkaji sampel hasil penilaian secara acak, untuk mendorong peserta didik supaya senantiasa melakukan penilaian diri secara cermat dan objektif. 6) Menyampaikan umpan balik kepada peserta didik berdasarkan hasil kajian terhadap sampel hasil penilaian yang diambil secara acak.

\section{DAFTAR RUJUKAN}

Asrul, Rusydi Ananda. (2014). “Evaluasi pembelajaran”. Bandung: Cita Pustaka Media.

Asrul, Rusydi,dkk.( 2014). Evaluasi pembelajaran. Bandung: Citapustaka Media. Azwar, Syaifuddin. (2005). Tes Prestasi, Fungsi dan pengembangan Pengukuran prestasi belajar. Yogyakarta: Pustaka Belajar.

Stambeek, Conny Semiawan. (1986). Prinsip Dan Teknik Pengukuran Dan Penilaian.

Departemen Agama RI. (2003). Penilaian Berbasis kelas. Jakarta: Direktorat Madrasah dan Pendidikan Agama Islam di Sekolah Umum.

Departemen Pendidikan Nasional. (2004). Pengembangan Sistem Penilaian, Didalam Dunia Pendidikan. Cet II. (Mutiara S. Wijaya). Jakarta: Direktorat Pendidikan Menengah Umum. 
Djemari Mardapi. (2012). Pengukuran, Penilaian, dan Evaluasi Pendidikan,

Elis ratnawulan\&Rusdiana. (2013). “Evaluasi Pembelajaran”. Bandung: Pustaka Setia.

M. Ngalim Purwanto. (2006). Prinsip- Prinsip dan Teknik Evaluasi Pengajaran, Bandung: Remaja Rosdakarya.

Masnur Muslich. (20110. Authentic Assessment: Penilaian Berbasis Kelas dan Kompetensi. Bandung: Refika Aditama.

Muhammad, M., \& Nurdyansyah, N. (2015). Pendekatan Pembelajaran Saintifik. Sidoarjo: Nizamia learning center.

Nasoetion, N. dan Suryanto, A. (1999). Evaluasi Pengajaran. Jakarta: Universitas Terbuka.

Nurdyansyah, N. (2015). Model Social Reconstruction Sebagai Pendidikan AntiKorupsi Pada Pelajaran Tematik di Madrasah Ibtida'iyah Muhammadiyah 1 Pare. Halaqa, 14(1).

Nurdyansyah, N. (2016). Developing ICT-Based Learning Model to Improve Learning Outcomes IPA of SD Fish Market in Sidoarjo. Jurnal TEKPEN, 1(2).

Nurdyansyah, N. (2017). Integration of Islamic Values in Elementary School. Atlantis Press. Advances in Social Science, Education and Humanities Research (ASSEHR), volume 125

Nurdyansyah, N. (2017). Sumber Daya dalam Teknologi Pendidikan. Universitas Muhammadiyah Sidoarjo.

Nurdyansyah, N. (2018). Model Pembelajaran Berbasis Masalah Pada Pelajaran IPA Materi Komponen Ekosistem. Universitas Muhammadiyah Sidoarjo.

Nurdyansyah, N. (2018). Pengembangan Bahan Ajar Modul Ilmu Pengetahuan Alambagi Siswa Kelas Iv Sekolah Dasar. Universitas Muhammadiyah Sidoarjo.

Nurdyansyah, N. (2018). Peningkatan Moral Berbasis Islamic Math Character. Universitas Muhammadiyah Sidoarjo.

Nurdyansyah, N., \& Andiek, W. (2015). Inovasi Teknologi Pembelajaran. Sidoarjo: Nizamia learning center.

Nurdyansyah, N., \& Andiek, W. (2017). Manajemen Sekolah Berbasis ICT. Sidoarjo: Nizamia learning center.

Nurdyansyah, N., \& Fahyuni, E. F. (2016). Inovasi Model Pembelajaran Sesuai Kurikulum 2013. Sidoarjo: Nizamia learning center.

Nurdyansyah, N., \& Fitriyani, T. (2018). Pengaruh Strategi Pembelajaran Aktif Terhadap Hasil Belajar Pada Madrasah Ibtidaiyah. Universitas Muhammadiyah Sidoarjo.

Nurdyansyah, N., Rais, P., \& Aini, Q. (2017). The Role of Education Technology in Mathematic of Third Grade Students in MI Ma'arif Pademonegoro Sukodono. Madrosatuna: Journal of Islamic Elementary School, 1(1), 37-46. 
Nurdyansyah, N., Siti, M., \& Bachtiar, S. B. (2017). Problem Solving Model with Integration Pattern: Student's Problem Solving Capability. Atlantis Press. Advances in Social Science, Education and Humanities Research, volume 173

Pandi, R., \& Nurdyansyah, N. (2017). An Evaluation of Graduate Competency in Elementary School. Atlantis Press. Advances in Social Science, Education and Humanities Research (ASSEHR), volume 125

Raka Joni, T., Penilaian Pencapaian Siswa-Mahasiswa, (Penataran Lokakarya Tahap II, Proyek Pengembangan Pendidikan Guru, Dep. P\&K, Jakarta 1980).

Sitiatava Rizema Putra. (2013). Desain Evaluasi Belajar Berbasis Kinerja, Yogyakarta: Diva Press.

Sitiatava Rizema Putra. (2013). Desain Evaluasi Belajar Berbasis Kinerja. Yogyakarta: Diva Press.

Sri Jutmini, Sukardi, dkk. (2007). Panduan evaluasi pembelajaran. Surakarta: tim pekerti-aa ppsp lpp universitas sebelas maret.

Sudijono, Anas. (2003). Strategi Penilaian Hasil Belajar Afektif pada pembelajaran Pendidikan Agama Islam. Journal Yogyakarta.

Suharsimi Arikunto. (2012). Dasar-Dasar Evaluasi Pendidikan Edisi 2. Jakarta: Bumi Aksara.

Syah, Muhibbin. (2008). “Evaluasi Pembelajaran”. Bandung: Pustaka Setia.

Zainul, A. (1992). Pengukuran, Tes dan Evaluasi Hasil Belajar. Jakarta: PAUUniversitas Terbuka. 